\title{
HUBUNGAN ANTARA KINERJA LINGKUNGAN DAN KINERJA KOMITE AUDIT DENGAN KUALITAS PENGUNGKAPAN CORPORATE SOCIAL RESPONSIBILITY
}

(Pada Perusahaan Mamufaktur di BEI)

\author{
Ivana Siregar \\ Lindrianasari \\ Komaruddin \\ Jurusan Akuntansi Fakultas Ekonomi dan Bisnis, Universitas Lampung \\ E-mail: siregar_ivana@yahoo.com
}

\begin{abstract}
This research is aiming investigated the relationship between environmental performance with the quality of corporate social responsibily disclosure, the relationship between audit commitee performance with environmental performance, and the relationship between audit commitee performance with the quality of corporate social responsibily disclosure. Environmental performance is measured by ISO 14001 certificate. The proxy of audit commitee performance are audit commitee meeting, audit commitee report, audit charter. The quality of corporate social responsibily disclosure is measured by CSR index from Global Reporting Initiative.

The number of samples used in this research were one hundred thirteen manufacturing company. The sampling method used purposive sampling method. Data are taken from annual report 2010-2011 of the manufacture companies listed on Indonesia Stock Exchange. The examined technique hypothesis is mutiple regression by using SPSS program.

The result showed that environmental performance has a positif significant relationship with the quality of Corpoate Social Responsibility disclosure as the first hypothesis. The second hypothesis showed that environmental performance has a positif and sgnificant relationship with audit commitee performance. The third hypothesis showed that audit commitee performance has a positif and sgnificant relationship with the quality of Corpoate Social Responsibility disclosure.
\end{abstract}

Keywords: Environmental Performance, Corporate Social Responsibility Disclosure, Audit Commitee.

\section{PENDAHULUAN}

Selama ini perusahaan dianggap sebagai lembaga yang dapat memberikan banyak keuntungan bagi masyarakat, di mana menurut pendekatan teori akuntansi tradisional, perusahaan harus memaksimalkan labanya agar dapat memberikan sumbangan yang maksimum kepada masyarakat. Namun seiring dengan berjalannya waktu, masyarakat semakin menyadari adanya dampak-dampak sosial yang ditimbulkan oleh perusahaan dalam menjalankan operasinya untuk mencapai laba maksimal, yang semakin besar dan semakin sulit untuk dikendalikan. Dampak sosial yang ditimbulkan antara lain banjir, pencemaran air 
dan lingkungan lainnya yang disebabkan oleh limbah sebagai efek samping dari kegiatan produksi perusahaan.

Di Indonesia, sekitar 15-20 persen dari limbah dibuang dengan baik, akan tetapi sisanya dibuang ke sungai yang tentunya akan menimbulkan masalah banjir. Selain banjir, masalah yang ditimbulkan oleh limbah pabrik adalah pencemaran air sungai yang mengakibatkan kualitas air bersih pun memburuk. Sekitar 85 persen kota-kota kecil dan 50 persen kota-kota besar membuang sampah mereka di tempat terbuka. Sekitar 75 persen limbah perkotaan dapat terurai dan dapat digunakan sebagai kompos dan biogas. Namun sisanya masih tak tertangani dan mengkibatkan kerusakan lingkungan (Ihsan, 2008:3).

Oleh karena itu, masyarakat pun memberikan tuntutan pada perusahaan untuk memperhatikan secara khusus dampak lingkungan yang timbul dari kegiatan produksi perusahaan. Perusahaan pun menanggapi dengan baik tuntutan masyarakat tersebut dengan mulai melakukan kegiatan - kegiatan peduli lingkungan yang terprogram dan dilakukan pencatatan khusus dan pengungkapan atas kegiatan itu sebagai anggaran biaya yang secara tidak langsung akan mendatangkan benefit bagi perusahaan itu sendiri. Konsep pengungkapan ini sering disebut dengan akuntansi lingkungan.

Penerapan akuntansi lingkungan di negara berkembang dapat dikatakan masih kurang, hal ini karena lemahnya sanksi hukum dan aturan tentang pelaksanaan kegiatan peduli lingkungan. Mobus, 2005 dalam Lindrianasari, 2007 menemukan bahwa terdapat hubungan yang negatif antara sangsi hukum dengan pengungkapan akuntansi lingkungan yang wajib dengan penyimpangan aturan yang dilakukan oleh perusahaan. Artinya, semakin keras sangsi hukum yang berlaku di suatu negara, akan semakin mengurangi penyimpangan aturan yang telah ditetapkan oleh pihak regulator. Hal ini menunjukan bahwa sesungguhnya pihak regulator memiliki kekuatan untuk menekan pihak perusahaan dalam meminimalisasikan dampak kerusakan lingkungan yang disebabkan oleh kegiatan usaha mereka.

Di Indonesia sendiri kelestarian lingkungan sudah menjadi kebijakan pemerintah pada setiap periode. Pada Pelita ketujuh melalui TAP MPR No. II/MPR/1998 tentang GBHN, dinyatakan "Kebijakan sektor Lingkungan Hidup, antara lain, megenai pembangunan lingkungan hidup diarahkan agar lingkungan hidup tetap berfungsi sebagai pendukung dan penyangga ekosistem kehidupan dan terwujudnya keseimbangan, keselarasan dan keserasian yang dinamis antara sistem ekologi, sosial ekonomi, dan sosial budaya agar dapat menjamin pembangunan nasional yang berkelanjutan" (GBHN, 1998). Begitu juga Undang Undang Republik Indonesia No. 23 Tahun 1997 tentang Pengelolaan Lingkungan Hidup.

Adanya peraturan tersebut membuat perusahaan di Indonesia memiliki rasa tanggung jawab untuk memperhatikan lingkungannya, yang sering disebut dengan Corporate Social Responsibility selanjutnya disingkat CSR. CSR sebagai konsep akuntansi yang baru adalah transparansi pengungkapan sosial atas kegiatan atau aktivitas sosial yang dilakukan oleh perusahaan, di mana transparansi informasi yang diungkapkan tidak hanya informasi keuangan perusahaan, tetapi perusahaan juga diharapkan mengungkapkan informasi mengenai dampak sosial dan lingkungan hidup yang diakibatkan aktivitas perusahaan (Rakhiemah dan Agustia, 2009). Hal ini dilakukan untuk menjaga reputasi perusahaan atau agar perusahaan bisa tetap berkelanjutan dan terhindar dari berbagai bentuk penolakan masyarakat. Penjelasan ini didukung oleh teori legitimasi (legitimacy theory) yang memberikan alternatif jawaban atas pertanyaan mengapa perusahaan mengungkapkan akuntansi lingkungan.

Aturan dalam pelaksanaan CSR sudah ditetapkan dalam UU No. 40 Tahun 2007 tentang Perseroan Terbatas (UU PT) yang mengatur jika perseroan yang menjalankan usaha dalam bidang atau berkaitan dengan sumber daya maka wajib melaksanakan tanggung jawab sosial atau lingkungan, jika tidak akan dikenakan sanksi sesuai peraturan perundangan- 
undangan. UU No. 25 Tahun 2007 tentang Penanaman Modal (UU PM) yang di dalamnya di atur jika setiap penanam modal wajib melaksanakan tanggung jawab sosial perusahaan dan wajib menjaga kelestarian lingkungan hidup.

Melihat banyaknya investor yang peduli akan kondisi lingkungan, maka suatu perusahaan harus meningkatkan kinerja lingkungannya supaya menarik investor atau para stakeholder untuk menanamkan sahamnya. Bukti bahwa perusahaan memikirkan kepentingan para stakeholder dan masyarakat sekitar, maka perusahaan melakukan kinerja lingkungan yang tinggi. Karena itu dapat disimpulkan bahwa perusahaan dengan kinerja lingkungan yang baik, akan meningkatkan simpati masyarakat dan investor.

Perusahaan dengan kinerja lingkungan yang baik juga terbukti memiliki kepedulian sosial yang lebih besar baik terhadap masyarakat maupun tenaga kerjanya. Perusahaan dengan kinerja lingkungan yang baik tersebut tidak hanya mengungkapkan mengenai kepedulian perusahan terhadap lingkungan tetapi juga mngenai kualitas produk, keamanan produk, tanggung jawab sosial perusahaan terhadap masyarakat sekitar, hingga kepedulian perusahaan terhadap keselamatan dan kesejahteraan tenaga kerjanya. Perusahaan yang peduli dengan kinerja lingkungannya tersebut berarti telah menerapkan CSR dengan sebagaimana semestinya terbukti dengan tinggi kepedulian lingkungan dan sosal yang tinggi (Rakhiemah dan Agustia, 2009).

Semakin berkembangnya inisiatif perusahaan dalam melakukan pengungkapan lingkungan, banyak peneliti yang mempertanyakan kualitas informasi yang disampaikan dalam pengungkapan akuntansi lingkungan. Studi di Australia menunjukkan adanya jurang (gap) antara pengungkapan lingkungan dan kinerja lingkungan. Penemuan ini menunjukkan bahwa kualitas pengungkapan itu belum memadai, karena tidak ada kesesuaian antara informasi yang diungkapkan dengan kinerja yang sesungguhnya (Lindrianasari, 2007). Karenanya, pengungkapan yang dilakukan perusahaan perlu diawasi secara khusus untuk meminimalisir adanya gap tersebut.

Komite audit merupakan alat bagi banyak pihak dalam menghindari kecurangan dan pelanggaran laporan keuangan dan juga merupakan pihak akhir yang memonitor proses pelaporan keuangan perusahaan, termasuk dalam hal ini memonitor kualitas pengungkapan CSR (Gantyowati dan Nugroho, 2009). Dengan demikian komite audit yang merupakan salah satu fungsi pengawasan dalam perusahaan, dapat dikatakan mempunya hubungan baik secara langsung maupun tidak langsung dengan tingkat kualitas pengungkapan yang dilakukan perusahaan.

Selain sebagai fungsi pengawas pelaporan keuangan perusahaan, komite audit yang dipimpin dewan komisaris pun melakukan pengawasan terhadap pihak manajemen perusahaan dalam menjalankan kinerjanya pada masing-masing fungsi. Dengan kata lain, kinerja komite audit dalam mengawasi pihak manajemen, memiliki andil besar dalam penilaian baik buruknya kinerja manajemen perusahaan yang dalam penelitian ini dikhususkan pada kinerja lingkungan.

Penelitian ini bertujuan untuk memberikan bukti empiris tentang adanya hubungan positif antara kinerja lingkungan dan kualitas pengungkapan CSR, hubungan positif antara kinerja lingkungan dan kinerja komite audit, serta hubungan positif antara kinerja komite audit dan kualitas pengungkapan CSR. Keberhasilan penelitian ini diharapkan dapat menjadi tambahan informasi kepada pihak yang berkaitan dengan penelitian ini serta dapat dijadikan dasar penelitian untuk peneliti selanjutnya. 


\section{KAJIAN TEORITIS DAN PENGEMBANGAN HIPOTESIS}

\section{Teori Legitimacy}

Operasi perusahaan harus sesuai dengan harapan dari masyarakat. Deegan, Robin dan Tobin (2002) dalam Fitriyani (2012) menyatakan legitimasi dapat diperoleh manakala terdapat kesesuaian antara keberadaan perusahaan tidak mengganggu atau sesuai (congruent) dengan eksistensi sistem nilai yang ada dalam masyarakat dan lingkungan. Ketika terjadi pergeseran yang menuju ketidaksesuaian, maka pada saat itu legitimasi perusahaan dapat terancam.

Dasar pemikiran teori ini adalah organisasi atau perusahaan akan terus berlanjut keberadaannya jika masyarakat menyadari bahwa organisasi beroperasi untuk sistem nilai yang sepadan dengan sistem nilai masyarakat itu sendiri. Teori legitimasi menganjurkan perusahaan untuk meyakinkan bahwa aktivitas dan kinerjanya dapat diterima oleh masyarakat. Perusahaan menggunakan laporan tahunan mereka untuk menggambarkan kesan tanggung jawab lingkungan, sehingga mereka diterima oleh masyarakat.

\section{Teori Pesinyalan (Signalling Theory)}

Teori ini menekankan kepada pentingnya informasi dikeluarkan oleh perusahaan terhadap keputusan investasi pihak di luar perusahaan. Informasi merupakan catatan penting suatu perusahaan baik di masa lalu, saat ini maupun di masa yang akan datang. Teori sinyal menunjukkan adanya asimetris informasi anatara manajemen perusahaan dan pihak-pihak yang berkepentingan dengan informasi tersebut dan mengemukakan tentang bagaimana perusahaan memberikan sinyal-sinyal kepada pengguna laporan keuangan.

Informasi yang dipublikasikan sebagai suatu pengumuman akan memberikan sinyal bagi investor dalam pengambilan keputusan investasi. Jika pengumuman tersebut mengandung nilai positif, maka diharapkan pelaku pasar akan bereaksi pada waktu pengumuman tersebut dan diterima oleh para pelaku pasar. Sinyal dapat berupa promosi atau informasi lain yang menyatakan bahwa perusahaan tersebut lebih baik daripada perusahaan lain (Jogiyanto, 2000). Sama halnya jika dikaitkan dengan hubungan kinerja dengan pengungkapan sosial atau lingkungan, yaitu jika suatu perusahaan memiliki kinerja finansial yang tinggi maka dapat memberikan sinyal positif bagi investor atau masyarakat melalui laporan keuangan atau laporan tahunan yang akan diungkapkan.

\section{Corporate Social Responsibility (CSR)}

CSR adalah mekanisme bagi suatu organisasi untuk secara sukarela mengintegrasikan perhatian terhadap lingkungan dan sosial ke dalam operasinya dan interaksinya dengan stakeholders yang melebihi tanggung jawab di bidang hukum (Darwin, 2004 dalam Anggraini, 2006). Kepedulian perusahaan yang menyisihkan sebagaian keuntungannnya (profit) bagi kepentingan pembangunan manusia (people) dan lingkungan (planet) secara berkelanjutan berdasarkan prosedur (procedure) yang tepat dan professional merupakan wujud nyata dari pelaksanaan CSR di Indonesia dalam upaya penciptaan kesejahteraan bagi masyarakat Indonesia.

Beragam cara yang dilakukan perusahaan untuk menjalankan CSR. Ada perusahaan yang mendirikan yayasan atau organisasi sosial perusahaan, bekerja sama dengan pihak lain atau dengan menjalankan sendiri CSR mulai dari perencanaan hingga implementasinya, serta 
ada juga perusahaan yang bergabung dalam sebuah konsorsium untuk secara bersama-sama menjalankan CSR.

\section{Pengungkapan Corporate Social Responsibility (CSR Disclosure)}

Menurut Chariri dan Ghozali (2007) pengungkapan dapat diartikan sebagai pemberian informasi bagi pihak-pihak yang berkepentingan terhadap informasi tersebut. Tujuan pengungkapan dikategorikan menurut Securities Exchange Commission (SEC) menjadi dua, yaitu 1) protective disclosure yang sebagai upaya perlindungan terhadap investor, dan 2) informative disclosure yang bertujuan memberikan informasi yang layak kepada pengguna laporan . Pengungkapan berkaitan dengan akuntansi pertanggungjawaban sosial bertujuan untuk menyediakan informasi yang memungkinkan dilakukan evaluasi pengaruh perusahaan terhadap masyarakat. Pengaruh kegiatan ini bersifat negatif, yang menimbulkan biaya sosial pada masyarakat, atau positif yang berarti menimbulkan manfaat sosial bagi masyarakat (Yuningsih, 2001 dalam Sitepu, 2011).

Ada 2 jenis pengungkapan dalam pelaporan keuangan yang telah ditetapkan oleh badan yang memiliki otoritas di pasar modal. Yang pertama adalah pengungkapan wajib (mandatory disclosure), yaitu informasi yang harus diungkapkan oleh emiten yang diatur oleh peraturan pasar modal di suatu Negara. Sedangkan yang kedua adalah pengungkapan sukarela (voluntary disclosure), yaitu pengungkapan yang dilakukan secara sukarela oleh perusahaan tanpa diharuskan oleh standar yang ada (Fitriyani, 2012). Pengungkapan sosial yang diungkapkan perusahaan merupakan informasi yang sifatnya sukarela. Pengungkapan sosial di Indonesia termasuk ke dalam kategori valuntary disclosure.

\section{Kinerja Lingkungan}

Kinerja lingkungan adalah kinerja perusahaan dalam menciptakan lingkungan yang baik (green) (Suratno et al., 2006). Perusahaan memberikan perhatian terhadap lingkungan sebagai wujud tanggung jawab dan kepedulian perusahaan terhadap lingkungan. Kinerja lingkungan dapat dilakukan dengan menerapkan akuntansi lingkungan.

Di Indonesia, kinerja lingkungan diukur dengan menggunakan PROPER dari KLH (Kementrian Lingkungan Hidup). PROPER melakukan peringkat hasil kinerja lingkungan dari KLH berdasarkan kinerja lingkungan dari setiap perusahaan agar dapat dibandingkan dengan masing-masing perusahaan untuk menjadi koreksi. Indikator kinerja lingkungan lainnya adalah AMDAL (uji BOD dan COD air). Pada studi AMDAL, dilakukan pengumpulan dan analisis data yang bertujuan untuk Menelaah, mengamati, dan mengukur rona lingkungan awal yang diprakirakan akan terkena dampak besar dari kegiatan pembangunan/industri, yang sangat penting terhadap lingkungan hidup. Tolak ukur kinerja lingkungan lainnya adalah GRI (Global Reporting Initiative). GRI merupakan pionir dalam pengembangan rerangka kerja pelaporan sustainability yang berisikan laporan ekonomi, lingkungan dan sosial sebagai pembanding laporan keuangan (Lindrianasari, 2007)

Sistem standardisasi internasional bidang sistem manajemen lingkungan adalah ISO (International Organization for Standardization) 14001. Perusahaan yang mengikuti program ISO 14001 dan mendapatkan sertifikasi setelah melalui penilaian khusus, dapat dikatakan telah melakukan kinerja lingkungan sesuai standar internasional. Pelaksanaan program sertifikasi ISO 14001 dapat dikatakan sebagai tindakan proaktif dari produsen yang dapat mengangkat citra perusahaan dan memperoleh kepercayaan dari konsumen. 


\section{Komite Audit}

Menurut Komite Nasional Kebijakan Corporate Governance mengenai Komite Audit adalah:

"Suatu komite yang beranggotakan satu atau lebih anggota dewan komisaris dan dapat meminta kalangan luar dengan berbagai keahlian, pengalaman, dan kualitas lain yang dibutuhkan untuk mencapai tujuan Komite Audit."

Menurut Keputusan Ketua Bapepam Nomor: Kep-41/PM/2003 dikatakan bahwa komite audit adalah komite yang dibentuk oleh dewan komisaris dalam rangka membantu melaksanakan tugas dan fungsinya.

Definisi lainnya mengatakan bahwa komite audit merupakan organ pendukung dewan komisaris yang bekerja secara kolektif dan berfungsi membantu dewan komisaris dalam melaksanakan tugasnya. Pembentukan komite audit harus dilengkapi dengan Piagam Komite Audit yang ditandatangani oleh komisaris utama dan direktur utama perseroan. Ketua maupun anggota komite audit diangkat dan diberhentikan oleh Rapat Dewan Komisaris.

Komite audit bertindak mandiri baik dalam pelaksanaan tugasnya maupun dalam pelaporan, dan bertanggung jawab langsung kepada dewan komisaris. Anggota komite audit sekurang-kurangnya terdiri dari 3 (tiga) orang dengan komposisi 2 (dua) orang anggota dewan komisaris dan 1 (satu) orang tenaga ahli yang bukan merupakan pihak internal perusahaan yang bersangkutan, dan memiliki keahlian, pengalaman dibidang audit dan kualitas lain yang diperlukan. Anggota komite audit yang berasal dari dewan komisaris perseroan bertindak sebagai ketua komite audit.

Berdasarkan Surat Edaran dari Direksi PT. Bursa Efek Jakarta No. SE-008/BEJ/12-2001 tanggal 7 Desember 2001 perihal keanggotaan komite audit, disebutkan bahwa :

- Jumlah anggota Komite Audit sekurang-kurangnya 3 (tiga) orang, termasuk Ketua Komite audit.

- Anggota Komite Audit yang berasal dari komisaris hanya sebanyak 1 (satu) orang. Anggota Komite Audit yang berasal dari komisaris tersebut harus merupakan Komisaris Independen perusahaan tercatat yang sekaligus menjadi Ketua Komite audit.

- Anggota lainnya dari komite audit adalah berasal dari pihak eksternal yang independen. Yang dimaksud pihak eksternal adalah pihak diluar perusahaan tercatat yang bukan merupakan komisaris, direksi dan karyawan perusahaan tercatat, sedangkan yang diamksud independen adalah pihak diluar perusahaan tercatat yang tidak memiliki hubungan usaha dan hubungan afiliasi dengan perusahaan tercatat, komisaris , direksi dan pemegang saham utama perusahaan tercatat dan mampu memberikan pendapat profesional secara bebas sesuai dengan etika profesionalnya, tidak memihak kepada kepentingan siapapun.

\section{Tugas Dan Fungsi Komite Audit}

Sesuai dengan Kep. 29/PM/2004, komite audit adalah komite yang dibentuk oleh dewan komisaris untuk membantu melaksanakan tugas dan fungsinya. Komite audit memiliki tugas terpisah dalam membantu dewan komisaris untuk memenuhi tanggung jawabnya dalam memberikan pengawasan secara menyeluruh (FCGI, 2002). Menurut Kepmen BUMN No. KEP-117/M-MBU/2002, komite audit bertugas membantu komisaris/dewan pengawas dalam memastikan efektivitas sistem pengendalian intern dan efektivitas pelaksanaan tugas eksternal auditor dan internal auditor. Sedangkan menurut Peraturan Bapepam LK No. 
IX.1.5, komite audit bertanggung jawab melakukan penelaahan atas informasi keuangan yang dikeluarkan perusahaan, melakukan penelaahan atas ketaatan perusahaan atas peraturan perundang-undangan di pasar modal dan peraturan perundang-undangan lainnya, serta Melakukan penelaahan atas pelaksanaan pemeriksaan oleh auditor eksternal. Selain itu, pada peraturan nomor delapan poin (b), dikatakan bahwa komite audit harus membuat laporan komite audit tentang kegiatan komite audit dalam satu tahun serta hasil notulensi rapat. Menurut peraturan Bapepam LK Nomor: Kep-643/BL/2012 komite audit harus mengadakan rapat minimal satu kali dalam tiga bulan, atau empat kali dalam satu tahun.

Pada umumnya tanggung jawab komite audit meliputi tiga bidang, yaitu :

1. Laporan Keuangan (Financial Reporting), adalah untuk memastikan bahwa laporan keuangan yang dibuat oleh manajemen telah memberikan gambaran yang sebenarnya tentang kondisi keuangan, hasil usahanya, serta rencana dan komitmen jangka panjang;

2. Tata Kelola Perusahaan (Corporate Governance), adalah untuk memastikan, bahwa perusahaan telah dijalankan sesuai undang-undang dan peraturan yang berlaku, melaksanakan usahanya dengan beretika, melaksanakan pengawasannya secara efektif terhadap benturan kepentingan dan kecurangan yang dilakukan oleh karyawan perusahaan.

3. Pengawasan Perusahaan (Corporate Control). Tanggung jawab Komite Audit untuk pengawasan perusahaan termasuk di dalamnya pemahaman tentang masalah serta halhal yang berpotensi mengandung risiko dan sistem pengendalian intern serta memonitor proses pengawasan yang dilakukan oleh auditor internal. Ruang lingkup audit internal harus meliputi pemeriksaan dan penilaian tentang kecukupan dan efektifitas sistem pengawasan intern.

Komite audit merupakan alat yang efektif untuk melakukan mekanisme pengawasan, sehingga dapat mengurangi biaya agensi dan meningkatkan kualitas pengungkapan perusahaan (Foker, 1992 dalam Wardhani, 2011). Penelitian yang dilakukan oleh Ho dan Wong (2001) dalam Wardhani, 2011) menyatakan bahwa keberadaan komite audit berpengaruh secara signifikan terhadap luas pengungkapan sukarela (voluntary disclosure) yang dilakukan perusahaan.

\section{Pengembangan Hipotesis}

\section{Ha1 : Terdapat hubungan positif antara kinerja lingkungan dan kualitas pengungkapan $C S R$.}

Preston (1981) dalam Lindrianasari (2007) menyatakan bahwa perusahaan yang memiliki kinerja lingkungan yang baik dan melakukan pengungkapan yang tinggi memposisikan mereka sebagai perusahaan yang memiliki aktifitas yang berguna dan kualitas pengungkapan ini juga didorong legitimasi terhadap masyarakat. Penelitian ini memperlihatkan adanya hubungan yang positif antara kinerja lingkungan dengan kualitas pengungkapan lingkungannya.

Hasil penelitian Lindrianasari (2007) juga menyatakan bahwa adanya hubungan positif sebesar $41 \%$ dengan tingkat signifikan 0,000 antara kinerja lingkungan dan kualitas pengungkapan CSR. Hal ini menunjukkan adanya hubungan yang positif antara kinerja lingkungan dengan kualitas pengungkapan CSR. 


\section{Ha2 : Terdapat hubungan positif antara kinerja lingkungan dan kinerja komite audit.}

Komite audit merupakan pihak independen perusahaan yang dipimpin oleh salah satu dewan komisaris yang salah satu fungsinya sebagai pengawas berjalannya tata kelola perusahaan dengan baik, seperti sistem informasi organisasi, struktur pengendalian intern organisasi, tingkat kepatuhan terhadap kebijaksanaan operasi, prosedur dan perencanaan, serta kualitas kinerja perusahaan. Komite audit, yang dipimpin oleh dewan komisaris melakukan rapat berkala beberapa kali dalam setahun untuk merembukkan hasil pengawasan mereka terhadap kinerja manajemen.

Penelitian Filatotchev et al. (2005) dalam Muamal (2011), menemukan bukti bahwa anngota dewan komisaris independen berpengaruh terhadap kinerja perusahaan. Sharma et al. (2009) melakukan penelitian terkait keberadaan komite audit dalam mekanisme good corporate governance dengan hasil bahwa frekuensi rapat yang dilakukan oleh komite audit berhubungan dengan besarnya ukuran atau jumlah anggota komite audit dan kinerja perusahaan. Adanya frekuensi rapat komite audit lebih banyak mengindikasikan bahwa pengawasan yang dilakukan oleh komite audit berjalan dengan efektif dalam arti bahwa tiap terjadi permasalahan dalam perusahaan dapat langsung dibahas dalam rapat komite audit sehingga dapat lebih cepat ditemukan penyelesaian sehingga tidak menurunkan kinerja perusahaan (Muamal, 2011). Salah satu kinerja perusahaan yang dibahas pada penelitian ini adalah kinerja lingkungan.

\section{Ha3 : Terdapat hubungan positif antara akuntabilitas auditor internal dan kualitas pengungkapan $C S R$.}

Komite audit sebagai badan pengawas yang independen dalam perusahaan memiliki tugas mengawasi penyusunan laporan keuangan. Salah satu laporan yang dibahas pada penelitian ini adalah pengungkapan CSR, dimana pengungkapan ini sedang menjadi sorotan publik karena banyak entitas saat ini sedang giat dalam melakukan pengungkapan CSR. Karena itu penting bagi komite audit untuk memperhatikan kualitas dan kesesuaian pengungkapan CSR dengan kinerja yang sebenarnya.

Foker (1992) dalam Wardhani (2011) mengatakan bahwa komite audit merupakan alat yang efektif untuk melakukan mekanisme pengawasan, sehingga dapat mengurangi biaya agensi dan meningkatkan kualitas pengungkapan perusahaan. Penelitian lainnya mengatakan bahwa keberadaan komite audit berpengaruh secara signifikan terhadap luas pengungkapan sukarela (voluntary disclosure) yang dilakukan perusahaan Ho dan Wong (2001) dalam Wardhani (2011). 
Model Penelitian

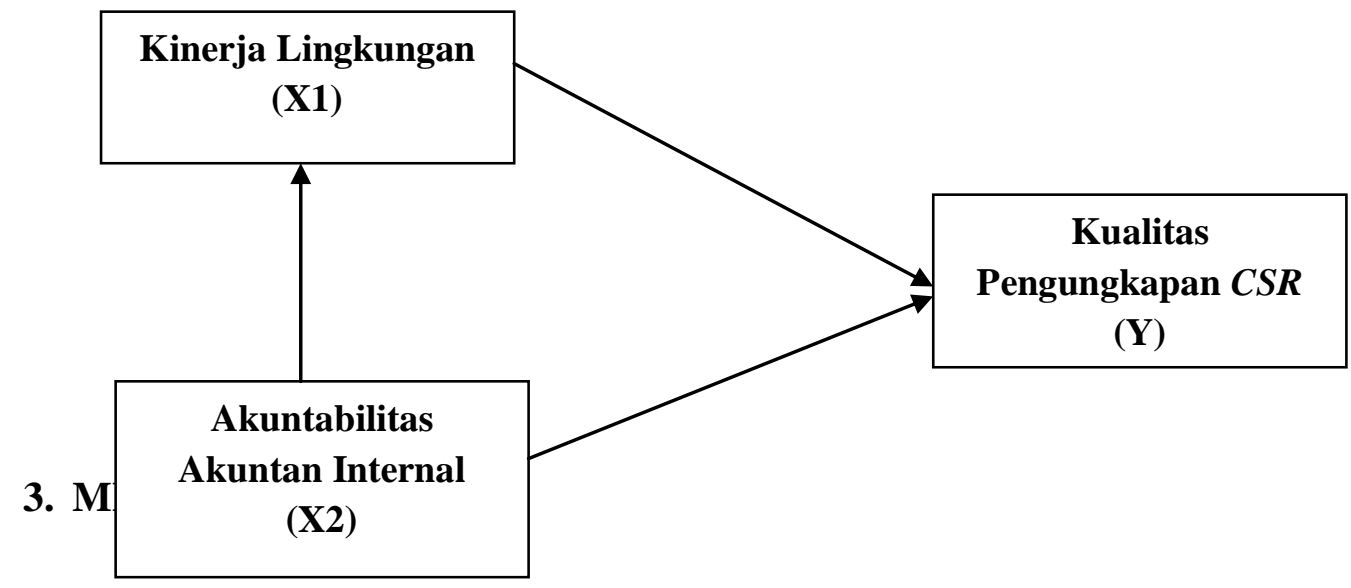

\subsection{Pemilihan Variabel Penelitian}

\section{Kinerja Lingkungan}

Pada penelitian ini, kinerja lingkungan perusahaan diukur dengan sertifikasi ISO 14001 yang merupakan sertifikasi terhadap Sistem Manajemen Lingkungan yang baik. ISO 14001 diberikan kepada perusahaan yang telah memiliki dan menjalankan SML dengan baik sesuai dengan standar dan kriteria yang diminta oleh ISO 14001. Untuk pengukurannya akan digunakan dummy variable, nilai 1 akan diberikan bagi perusahaan manufaktur yang mendapatkan sertifikasi ISO 14001, dan nilai 0 untuk perusahaan yang belum bersertifikasi ISO 14001.

\section{Kualitas Pengungkapan Corporate Social Responsibility (CSR)}

Corporate Social Responsibility (CSR) disclosure diukur dengan menggunakan Index CSR Majemuk. Kategori Pengungkapan CSR menggunakan standar dari GRI ( Global Reporting Initiative). GRI terdiri dari 3 fokus pengungkapan, yaitu ekonomi, lingkungan dan sosial sebagai dasar sustainability reporting (Dahlia dan Siregar, 2008).

Dalam GRI berisi beberapa indikator yaitu :

1. Indikator Kinerja finansial

2. Indikator Kinerja Lingkungan

3. Indikator Kinerja Tenaga Kerja

4. Indikator Kinerja Hak Asasi Manusia

5. Indikator Kinerja Sosial

6. Indikator Kinerja Produk

Pada penelitian ini indikator yang dipakai hanya lima yaitu, kinerja finansial, kinerja tenaga kerja, kinerja hak asasi manusia, kinerja sosial, dan kinerja produk. Pendekatan untuk menghitung CSDI pada dasarnya menggunakan dikotomi yaitu setiap item CSR dalam instrumen penelitian diberi nilai 1 jika diungkapkan, dan nilai 0 jika tidak diungkapkan (Haniffa et al., 2005 dalam Sudaryanto, 2011).

Indeks pengungkapan masing-masing perusahaan kemudian dihitung dengan membagi jumlah item yang diungkapkan perusahaan dengan jumlah item yang diharapkan 
diungkapkan perusahaan ini konsisten dengan penelitian yang sebelumnya yang dilakukan di Indonesia (Utomo, 2000; Henny dan Murtanto, 2001; dan Hasibuan, 2001), yang dinyatakan dalam Corporate Social Responsibility Index (CSRI) dengan rumus sebagai berikut :

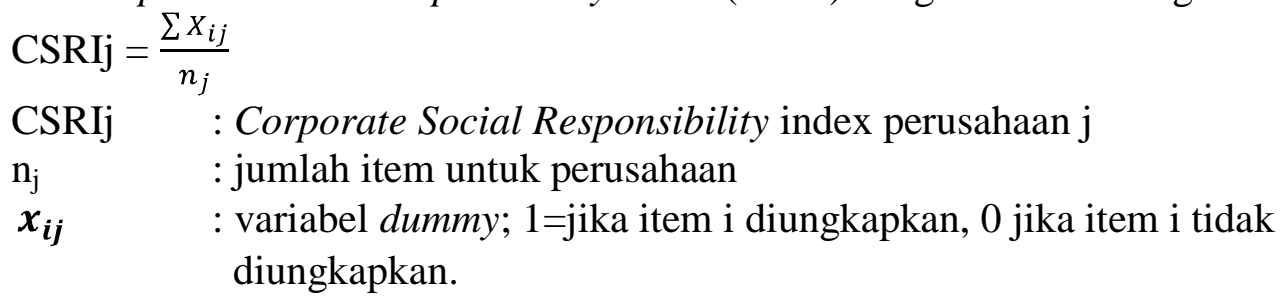

Dengan demikian, $0 \leq \mathrm{CSRI}$; $\mathrm{nj} \leq 1$

\section{Kinerja Komite Audit}

Seperti yang telah diulas dalam tinjauan pustaka tentang aturan Bapepam LK Nomor: Kep-643/BL/2012, komite audit harus melakukan rapat atau pertemuan komite audit minimal satu kali dalam tiga bulan yang artinya dalam satu tahun komite audit wajib menyelenggarakan rapat sebanyak empat kali. Selain itu berdasarkan peraturan Bapepam LK No. IX.1.5, dikatakan bahwa komite audit wajib membuat laporan tahunan atas aktifitasnya dan hasil notulensi rapat, pada poin lainnya disebutkan bahwa komite audit wajib membuat audit charter sebagai pedoman kerjanya.

Oleh karena itu, sebagai indikator untuk mengukur kinerja komite audit pada penelitian ini, diambil tiga kriteria kinerja komite audit yaitu rapat komite audit, laporan komite audit, serta piagam audit. Bagi objek yang memiliki ketiga kriteria tersebut akan diberu score 3, jika hanya dua diantaranya akan mendapat score 2 , jika hanya satu akan mendapat score 1.

\section{Ukuran Perusahaan}

Ukuran perusahaan (size) perusahaan merupakan variabel penduga yang banyak digunakan untuk menjelaskan variasi pengungkapan dalam laporan tahunan perusahaan. Hal ini dikaitkan dengan teori agensi, dimana perusahaan besar yang memiliki biaya keagenan yang lebih besar akan mengungkapkan informasi yang lebih luas untuk mengurangi biaya keagenan tersebut. Di samping itu perusahaan besar merupakan emiten yang banyak disoroti, pengungkapan yang lebih besar merupakan pengurangan biaya politis sebagai wujud tanggung jawab sosial perusahaan (Sembiring, 2005).

Size perusahaan bisa didasarkan pada jumlah aktiva (aktiva tetap, tidak berwujud dan lain-lain), jumlah tenaga kerja, penjualan dan kapitalisasi pasar. Pada penelitian ini, ukuran perusahaan yang dipakai sebagai variabel kontrol diukur dari penjualan perusahaan selama satu tahun yang di-log natural terlebih dahulu sebelum diolah karena range nilainya yang jauh berbeda antar perusahaan sampel.

\subsection{Pemilihan Sampel}

Metode pengambilan sampel yang akan digunakan dalam penelitian ini adalah metode judgement sampling, yaitu salah satu bentuk purposive sampling dengan mengambil sampel yang telah ditentukan sebelumnya berdasarkan maksud dan tujuan penelitian dengan kriteria sebagai berikut:

1. Perusahaan yang bergerak di bidang manufaktur yang menerbitkan dan mempublikasikan laporan tahunan (annual report) periode 2010-2011. 
2. Perusahaan manufaktur yang berkonsentrasi pada pengungkapan informasi lingkungan yang dipaparkan di laporan tahunan (annual reports) dan website. Sampel akan diambil dari total populasi perusahaan manufaktur yang tercatat go public di BEI tahun 2010-2011 adalah 139 perusahaan yang terbagi dalam 20 kategori perusahaan. Penelitian ini mengambil periode analisis tahun 2010-2011.

Tabel 1. Pemilihan Sampel

\begin{tabular}{|c|l|c|}
\hline No & \multicolumn{1}{|c|}{ Kriteria } & Akumulasi \\
\hline 1 & Perusahaan manufaktur yang listing di BEI 2010-2011 & 131 \\
\hline 2 & $\begin{array}{l}\text { Perusahaan yang tidak dipakai: } \\
\bullet \quad \text { Data tidak lengkap }\end{array}$ & (18) \\
\hline 3 & \begin{tabular}{l} 
Jumlah sampel perusahaan \\
\hline
\end{tabular}
\end{tabular}

\subsection{Metode Analisis}

Jika suatu variabel dependen bergantung pada lebih dari satu variabel independen, hubungan antara kedua variabel disebut analisis regresi berganda (multiple regression) (Sulaiman, 2004). Hasil pengujian tersebut akan memberikan hasil dari penolakan atau penerimaan dari hipotesis penelitian. Penelitian ini menggunakan software SPSS untuk memprediksi hubungan antara variabel independen dengan variabel dependen. Adapun persamaan untuk menguji hipotesis secara keseluruhan dalam penelitian ini adalah sebagai berikut:

Keterangan :

$$
\mathrm{Y}=\alpha+\beta x_{1}+\beta x_{2}+\beta x_{3}+\mathrm{e}
$$

$\mathrm{Y} \quad=$ Kualitas pengungkapan CSR

$\alpha \quad=$ Konstanta

$x_{1}=$ ISO 14001

$x_{2}=$ Kriteria komite audit

$x_{3}=$ Total penjualan

$\beta_{1} \quad=$ Koefisien variabel kinerja lingkungan

$\beta_{2} \quad=$ Koefisien variabel kinerja komite audit

$\beta_{3} \quad=$ Koefisien variabel ukuran perusahaan

$\mathrm{e} \quad=$ error

\section{Uji Hipotesis}

Analisis regresi linier, analisis jalur dan sobel test digunakan untuk menguji hipotesis dalam penelitian ini. Analisis jalur merupakan perluasan dari analisis regresi berganda, atau dengan kata lain analisis jalur adalah penggunaan analisis regresi untuk menaksir hubungan kausalitas antar variabel yang telah ditetapkan sebelumnya berdasarkan teori. Persamaannya antara lain adalah sebagai berikut:

CSRD

$\mathrm{KL}$

$$
\begin{aligned}
& =a+b K L+c K K A+e \\
& =a+c K K A+e
\end{aligned}
$$


Keterangan :
a $\quad=$ Konstanta
$\mathrm{b}, \mathrm{c} \quad=$ Koefisien regresi
e $\quad$ error

Untuk mengetahui kebenaran prediksi dari pengujian regresi yang dilakukan, maka dilakukan pencarian nilai koefisien determinasi (adjusted R2). Uji F juga digunakan untuk mengetahui apakah semua variabel independen secara simultan merupakan penjelas yang signifikan terhadap variabel dependen. Sedangkan pengujian untuk mendukung hipotesis adalah dengan uji t yaitu seberapa jauh pengaruh variabel dependen.

\section{HASIL DAN PEMBAHASAN}

\section{Analisis Korelasi}

Tabel 2 Korelasi Variabel

\begin{tabular}{|l|l|c|c|}
\hline No & \multicolumn{1}{|c|}{ Hipotesis } & Korelasi & Signifikan \\
\hline 1. & $\begin{array}{l}\text { Kinerja lingkungan - Kualitas pengungkapan } \\
\text { (KL - CSR) }\end{array}$ & $85,9 \%$ & 0,000 \\
\hline 2. & $\begin{array}{l}\text { Kinerja lingkungan - Akuntabilitas auditor } \\
\text { internal (KL - KKA) }\end{array}$ & $83,3 \%$ & 0,000 \\
\hline 3. & $\begin{array}{l}\text { Akuntabilitas auditor internal - Kualitas } \\
\text { pengungkapan (KKA - CSR) }\end{array}$ & $95,4 \%$ & 0,000 \\
\hline
\end{tabular}

Tabel di atas menunjukkan hubungan antara variabel kinerja lingkungan dan komite audit terhadap kualitas pengungkapan CSR. Dari hasil perhitungan didapatkan hubungan positif antara kinerja lingkungan dengan kinerja komite audit dengan probabilitas atau signifikan 0,000 dan koefisien korelasi 0,833 dengan kata lain hubungan antar kinerja komite audit dengan kinerja lingkungan adalah erat. Hasil perhitungan hubungan kinerja lingkungan dengan kualitas pengungkapan CSR menghasilkan probabilitas 0,000 dan koefesien korelasi 0.859 sedangkan hubungan antara kinerja komite audit dengan kualitas pengungkapan CSR terdapat hubungan positif sebesar 0.954 dengan tingkat signifikan 0,000 . Ketiga variabel memiliki hubungan yang sangat erat. 
Tabel 3. Partial Correlation dengan Control Variables

Correlations

\begin{tabular}{|c|c|c|c|c|c|}
\hline \multicolumn{3}{|c|}{ Control Variables } & $\mathrm{KL}$ & KKA & CSR \\
\hline \multirow[t]{9}{*}{$\mathrm{NP} 2$} & $\mathrm{KL}$ & Correlation & 1.000 & .832 & .858 \\
\hline & & $\begin{array}{l}\text { Significance (2- } \\
\text { tailed) }\end{array}$ & & .000 & .000 \\
\hline & & Df & 0 & 110 & 110 \\
\hline & KKA & Correlation & .832 & 1.000 & .954 \\
\hline & & $\begin{array}{l}\text { Significance (2- } \\
\text { tailed) }\end{array}$ & .000 & & .000 \\
\hline & & Df & 110 & 0 & 110 \\
\hline & CSR & Correlation & .858 & .954 & 1.000 \\
\hline & & $\begin{array}{l}\text { Significance (2- } \\
\text { tailed) }\end{array}$ & .000 & .000 & \\
\hline & & Df & 110 & 110 & 0 \\
\hline
\end{tabular}

\section{Sumber: Data Sekunder 2013, diolah.}

Pada tabel di atas ditunjukkan bahwa terdapat empat variabel dalam pengolahan data ini yaitu dua variabel bebas, satu varibael terikat dan variabel kontrol. Variabel bebas pada pengolahan data ini adalah kinerja lingkungan dan kinerja komite audit, variabel terikat yang di tentukan adalah kualitas pengkungkapan CSR serta variabel kontrolnya adalah nilai penjualan.

Keterkaitan antara variabel-variabel tersebut menjelaskan mengenai hubungan antara tiap-tiap variabel yang dibantu oleh variabel kontrol. Hasil uji korelasi keseluruhan variabel dengan variabel kontrol menunjukkan kinerja komite audit mempunyai hubungan yang positif dengan kinerja lingkungan sebesar 0.832 dengan signifikan 0.000 , kinerja komite audit mempunyai hubungan yang positif dengan kualitas pengungkapan CSR sebesar 0.954 dengan signifikan 0.000 , serta kinerja lingkungan mempunyai hubungan yang positif dengan kualitas pengungkapan CSR sebesar 0.858. Dari pemaparan tersebut dapat disimpulkan semua hipotesis yang diajukan diterima. 
Analisis Regresi

Tabel 4. Hasil analisi Regresi Linier Berganda Coefficients $^{\mathrm{a}}$

\begin{tabular}{|c|c|c|c|c|c|c|}
\hline \multirow{2}{*}{\multicolumn{2}{|c|}{ Model }} & \multicolumn{2}{|c|}{$\begin{array}{c}\text { Unstandardized } \\
\text { Coefficients }\end{array}$} & \multirow{2}{*}{$\begin{array}{c}\text { Standardized } \\
\text { Coefficients } \\
\text { Beta }\end{array}$} & \multirow[b]{2}{*}{$\mathrm{t}$} & \multirow[b]{2}{*}{ Sig. } \\
\hline & & B & Std. Error & & & \\
\hline 1 & (Constant) & .158 & .031 & & 5.085 & .000 \\
\hline & KL & .135 & .031 & .210 & 4.377 & .000 \\
\hline & KKA & .226 & .014 & .779 & 16.265 & .00 \\
\hline & NP2 & .001 & .004 & .005 & .178 & .85 \\
\hline
\end{tabular}

a. Dependent Variable: CSR

\section{Sumber: Data Sekunder 2013, diolah.}

Persamaan regresi linear berganda dirumuskan:

$\mathbf{Y}=\mathbf{a}_{0}+\mathbf{b}_{1} \mathbf{X}_{1}+\mathbf{b}_{2} \mathbf{X}_{2}+\mathbf{b}_{3} \mathbf{X}_{3}$

Berdasarkan tabel dapat disusun persamaan regresi linear berganda sebagai berikut:

$\mathrm{Y}=\mathbf{0 , 1 5 8}+\mathbf{0 , 2 1 0 X 1}+\mathbf{0 , 7 7 9} \mathrm{X} 2+\mathbf{0 . 0 0 5 X 3}$

Hasil perhitungan di atas diketahui nilai signifikan kinerja lingkungan sebesar 0.000 dan kinerja komite audit sebesar 0.000. Penggunaan alat analisis regresi berganda ditujukan untuk melihat besarnya hubungan antara kinerja lingkungan dan kineja komite audit dengan kualitas pengungkapan CSR menggunakan bantuan progran SPSS 17.0 for Windows. Berdasarkan hasil perhitungan didapatkan persamaan $\mathrm{Y}=0,156+0,210 \mathrm{X} 1+0,779 \mathrm{X} 2+$ 0.005X3. Dari perhitungan tersebut didapat probabilitas kinerja lingkungan dan kineja komite audit dengan kualitas pengungkapan CSR adalah 0,210 dan 0,799 atau sebesar 21\% dan $79,9 \%$.

\section{Hasil Uji Hipotesis}

\section{Pengujian Hipotesis Pertama}

Hipotesis pertama berbunyi terdapat hubungan yang positif signifikan kinerja lingkungan dengan kualitas pengungkapan CSR. Dari hasil analisis menggunakan SPSS 17.0 didapatkan hasil bahwa terdapat hubungan positif signifikan antara kinerja lingkungan terhadap kualitas pengungkapan CSR karena (Nilai T hitung 17,640 > T tabel 1.96). Hal ini dilihat dari nilai 0,859 yang berarti indikator kinerja lingkungan berpengaruh pada indikator kualitas pengungkapan CSR. Dengan kata lain perusahaan yang melakukan program kinerja lingkungan dengan baik akan mendukung kualitas pengungkapan CSR perusahaan yang baik.

\section{Pengujian Hipotesis Kedua}

Hipotesis kedua menyatakan bahwa terdapat hubungan yang positif signifikan antara kinerja komite audit dengan kualitas pengungkapan CSR. Berdasarkan hasil pengujian didapat nilai T hitung 33,482 > T tabel 1,98 dan koefesien korelasi 0,954 yang berarti bahwa hubungan antara antara kinerja komite audit dengan kualitas pengungkapan CSR memiliki hubungan yang positif dan signifikan. Hal ini menggambarkan kinerja komite audit yang 
baik di dalam perusahaan akan mendukung kualitas pengungkapan CSR yang baik. Hipotesis menyatakan bahwa terdapat hubungan yang positif signifikan antara kinerja komite audit dengan kualitas pengungkapan CSR diterima.

\section{Pengujian Hipotesis Ketiga}

Hipotesis ketiga menyatakan bahwa terdapat hubungan yang positif signifikan antara kinerja komite audit dengan kinerja lingkungan. Dari hasil analisis menggunakan SPSS 17.0 didapatkan hasil bahwa terdapat hubungan positif antara kinerja komite audit dengan kinerja lingkungan signifikan karena nilai T Hitung 15,842 < T Tabel 1,98. Hal ini terlihat dari nilai koefesien korelasi 0,833 yang berarti indikator kinerja lingkungan berpengaruh pada indikator kualitas pengungkapan CSR.

\section{SIMPULAN DAN SARAN}

\section{Simpulan} penelitian.

Untuk mempermudah membaca hasil penelitian ini, maka dibuat tabel simpulan hasil

Tabel 5. Simpulan Penelitian

\begin{tabular}{|l|l|c|c|c|}
\hline & \multicolumn{1}{|c|}{ Hipotesis } & Korelasi & Signifikansi & Simpulan \\
\hline Ha1 & $\begin{array}{l}\text { Kinerja lingkungan - } \\
\text { Kualitas pengungkapan } \\
\text { CSR }\end{array}$ & $85,9 \%$ & 0,000 & $\begin{array}{c}\text { Ha1 } \\
\text { diterima }\end{array}$ \\
\hline Ha2 & $\begin{array}{l}\text { Kinerja lingkungan - } \\
\text { Akuntabilitas auditor } \\
\text { internal }\end{array}$ & $83,3 \%$ & 0,000 & $\begin{array}{c}\text { Ha2 } \\
\text { diterima }\end{array}$ \\
\hline Ha3 & $\begin{array}{l}\text { Akuntabilitas auditor } \\
\text { internal - Kualitas } \\
\text { pengungkapan CSR }\end{array}$ & $95,4 \%$ & 0,000 & $\begin{array}{c}\text { Ha3 } \\
\text { diterima }\end{array}$ \\
\hline
\end{tabular}

Penelitian ini betujuan memberikan bukti empiris tentang signifikansi hubungan antara kinerja lingkungan dengan kualitas pengungkapan CSR, hubungan positif antara kinerja komite audit dengan kualitas pengungkapan CSR, dan hubungan positif antara kinerja komite audit dengan kinera lingkungan. Setelah melakukan penelitian dengan pengolahan data sekunder yang dianbil dari annual report perusahaan manufaktur yang listing di BEI, didapatkan beberapa hasil, yaitu:

1. Adanya hubungan positif signifikan antara kinerja lingkungan dengan kualitas pengungkapan CSR. Hal ini berarti kualitas pengungkapan CSR yang baik dapat didukung dengan pelaksanaan kinerja lingkungan yang baik.

2. Adanya hubungan yang positif signifikan antara kinerja komite audit dengan kinerja lingkungan. Hal ini berarti dengan kinerja komite audit yang baik, maka kinerja lingkungan perusahaan akan baik pula. 
3. Adanya hubungan yang positif signifikan antara kinerja komite audit dengan kualitas pengungkapan CSR. Hal ini berarti kinerja komite audit yang baik akan mendukung kualitas pengungkapan CSR.

\section{Keterbatasan}

Terdapat beberapa keterbatasan pada penelitian ini, antara lain:

- Variabel kinerja lingkungan hanya menggunakan satu indikator yaitu ada/tidaknya sertifikasi ISO 14001, sedangkan variabel lainnya menggunakan beberapa indikator konstruk.

- Indikator untuk kualitas pengungkapan CSR sebenarnya belum cukup memadai, diperlukan penelitian lebih lanjut untuk mengetahui kualitas sesungguhnya dari pengungkapan CSR tersebut.

- Pemilihan sampel akhir didasarkan ketersediaan data dan informasi yang disajikan dalam annual report, namun beberapa informasi tidak lengkap sehingga dikeluarkan dari sampel agar tidak menimbulkan kesalahan.

\section{Saran}

Melihat hasil penelitian ini, maka peneliti memberikan beberapa sanan berikut:

- Bagi pemerintah, diharapkan pemerintah dapat terus mengembangkan regulasi tentang peduli lingkungan bagi perusahaan-perusahaan di Indonesia baik sektor pemerintahan maupun sektor swasta, khususnya perusahaan yang kegiatan produksinya menimbulkan dampak lingkungan yang perlu dikendalikan.

- Bagi Bapepam, dapat merekomendasikan perusahaan-perusahaan yang giat melakukan aktivitas peduli lingkungan, agar calon-calon investor lebih tertarik menanamkan modalnya pada perusahaan yang kinerja lingkungannya baik. Hal ini akan memacu perusahaan-perusahaan lain untuk lebih giat melakukan kegiatan peduli lingkungan. Selain itu, Bapepam perlu mengawasi kinerja komite audit lebih lanjut.

- Bagi pihak manajemen perusahaan, diharapkan membuat program tanggung jawab sosial lebih baik lagi dan penuh dengan kesadaran, karena di samping memberikan kenyamanan bagi masyarakat di sekitar lingkungan produksi perusahaan, secara tidak langsung perusahaan juga mendapatkan feedback positif dari kegiatan peduli lingkungan yang dilakukan.

- Bagi komite audit yang memiliki fungsi pengawasan dalam perusahaan, diharapkan dapat berkonsentrasi juga dalam pengawasan kinerja lingkungan dan pengungkapannya.

- Bagi peneliti selanjutnya disarankan mencari informasi yang lebih lengkap lagi dan mencari beberapa indikator yang lebih representatif untuk mengukur setiap variabel yang dipakai dalam penelitian. 
DAFTAR PUSTAKA

Ahmad, N.N.N., dan Sulaiman, M. (2004), "Environmental Disclosures in Malaysian Annual Reports: A Legitimacy Theory Perspective". International Journal of Commerce and Management, 14, 44.

Astuti, Dewi Saptantinah Puji. 2010. "Peran Internal Audit dan Komite Audit dalam Mewujudkan Good Corporate Governance”. Jurnal Akuntansi dan Sistem Teknologi Informasi, 8 (1); 1 - 9

Beasley, Mark S. 1996. An Empirical Analysis of the Relation Between the Board of Director Composition and Financial Statement Fraud. The Accounting Review, 71 (4); 443-465

Chandra, Ferdinand Kris. 2006. "Pengaruh Tindakan Supervisi Terhadap Kinerja Auditor Internal dengan Motivasi Kerja Sebagai Variabel Intervening." http://eprints.undip.ac.id/15599

Dahlia, D., \& Siregar, S.V. (2008). "Pengaruh Corporate Social Responsibility Terhadap Kinerja Perusahaan (studi empiris pada perusahaan yang tercatat di Bursa Efek Indonesia tahun 2005 dan 2006)." Simposium Nasional Akuntansi XI, Pontianak.

Effendi, Muhammad Arief. 2005. "Peranan Komite Audit Dalam Meningkatkan Kinerja Perusahaan.” Jurnal Akuntansi Pemerintah, 1 (1); 51-57

Fitriyani, (2012). "Keterkaitan Kinerja Lingkungan, Pengungkapan Corporate Social Responsibility (CSR), dan Kinerja Financial." http://eprints.undip.ac.id/35522/1/Skripsi_30.pdf

Fr. Reni. Retno Anggraini, (2006). Pengungkapan Informasi Sosial dan Faktor Faktor yang Mempengaruhi Pengungkapan Informasi Sosial dalam Laporan Keuangan Tahunan (Studi Empiris pada Perusahaan-Perusahaan yang terdaftar Bursa Efek Jakarta).Simposium Nasional Akuntansi IX Padang, K-AKP M 24.

Gantyowati, Evi \& Nugroho, Dhinar Adi. 2009. "Pengaruh Komisaris Independen Dan Komite Audit Terhadap Pengurangan Asimetri Informasi Di Sekitar Pengumuman Laba.” Jurnal Siasat Bisnis, 13 (3); 253-265

Ghozali, Imam \& Anis Chariri. Teori Akuntansi. 2007. Semarang: UNDIP

Ghozali, Imam. 2013. "Structural Equation Modeling Metode Alternatif Dengan Partial Least Square". Semarang: UNDIP

Gray R., Javad M., David M.P., \& Donald S. 2001. "Social And Enviromental Disclosure And corporate Characteristics: A Research Note and Extension". Journal of Business Finance and Accounting, 44 (5); 327-356 
Halim Abdul ,Arif Surya Irawan, 1998, Perspektif Akuntansi Lingkungan, Suatu Tinjauan Teoritis Mengenai Isu Dampak Lingkungan Terhadap Akuntansi, Jurnal Ekonomi dan Bisnis Indonesia, 33 (3);

Ihsan, Arfan. 2008. Akuntansi Lingkungan dan Pengungkapannya. Yogyakarta: Graha Ilmu

Jogiyanto.2000. Sistem Informasi Berbasis Komputer Konsep Dasar dan Komponen Edisi Kedua. Yogyakarta:BPFE

Hasibuan, Malayu. 2001. Manajemen Sumber Daya Manusia:Pengertian Dasar, Pengertian, dan Masalah. Jakarta: PT. Toko Gunung Agung

Ja'far, S, Muhammad dan Arifah, Dista Amalia, 2006. "Pengaruh Dorongan Manajemen Lingkungan, Manajemen Lingkungan Proaktif dan Kinerja Lingkungan Publik Environmental Reporting." Simposium Nasional Akuntansi IX Padang.

Kirana, Rosita Chandra. 2009. "Studi Perbandingan Pengaturan tentang CSR Di Beberapa Negara dalam Upaya Perwujudan Prinsip Good Corporate Governance". digilib.uns.ac.id/pengguna.php?mn=detail\&d_id=1583.

Lindrianasari, (2007). Hubungan Antara Kinerja Lingkungan dan Kualitas Pengungkapan Lingkungan dengan Kinerja Ekonomi Perusahaan di Indonesia. Jurnal Akuntansi dan Auditing Indonesia, 11 (2); 159-166

Muamal, Khairunnisa. 2011. "Peranan Komite Audit Terhadap Kinerja Manajemen Rumah Sakit Umum Daerah.” http://eprints.undip.ac.id/33131/1/Skripsi_17

Mulyadi \& Kanaka Puradiredja. 1998. Auditing Buku I. Jakarta : Salemba Empat

Nasution, Manahan. 2003. "Sekilas Tentang Internal Auditor”. Jakarta: Salemba Empat. Jurnal. Medan: Fakultas Ekonomi Universitas Sumatera Utara.

Rakhiemah A.N., \& Agustia D. 2009. "Pengaruh Kinerja Lingkungan terhadap Corporate Social Responsibility (CSR) Disclosure dan Kinerja Finansial Perusahaan Manufaktur yang Terdaftar di Bursa efek Indonesia." Simposium Nasional Indonesia 12. Palembang

Rahmawati, (2012). "Pengaruh Kinerja Lingkungan Terhadap Corporate Financial Perfomance dengan Corporate Social Responsibility sebagai variabel Intervening." http://eprints.undip.ac.id/35522

Sembiring. 2005. "Karakteristik Perusahaan dan Pengungkapan Tanggung Jawab Sosial : Study Empiris pada Perusahaan yang tercatat di Bursa Efek Jakarta." Simposium Nasional Akuntansi 8. 
Suratno, Darsono, dan Siti Mutmainah. 2006. "Pengaruh Environmental Performance Terhadap Environmental Disclosure Dan Economic Performance: Studi Empiris Pada Perusahaan Manufaktur Yang Terdaftar Di Bursa Efek Jakarta Periode 2001-2004”. SNA IX Padang. 23-26 Agustus.

Triani, RR. 2010. Analisis Hubungan Antara Kinerja Ekonomi Dan Kinerja Lingkungan Dengan Alokasi Dana CSR Pada Perusahaan Ekstraktif. http://eprints.undip.ac.id/22701

Wardhani, Saskiya Rahma. 2011. "Hubungan Antara Karakteristik Good Corporate Governance Dan Pengungkapan Tanggung Jawab Sosial Pada Sektor Finansial.” eprints.undip.ac.id/29488/1/Skripsi012

Yamin, Sofyan dan Kurniawan Heri. 2009. "Structural Equation Modeling". Jakarta: Salemba Infotek.

www.bpkp.go.id/public/upload/unit/investigasi/.../cegah_deteksi.pdf www.nqa.com/in/atozservices/article.asp?SECTION=274...253 www.saulpurwoyo.tripod.com/id6.html www.iso14000-iso14001-environmental-management.com/iso14001.html 
Sengaja Dikosongkan 